\title{
Publishing and Readerships
}

\author{
Henning Hansen and Maria Purtoft
}

The relations between the authors of the Scandinavian Modern Breakthrough and their contemporary domestic audiences have often been characterized in negative terms, ranging from indifference to tensions, or even outright hostility. This view originated with some of the protagonists of the new literature themselves, not least Georg Brandes, and it has influenced the perception of the Modern Breakthrough since then. Recent scholarship has challenged this view, highlighting the extraordinary success of Ibsen, in particular, in his Scandinavian home markets. This chapter will present further evidence on Ibsen's publishing history as well as recent research into the composition of his Scandinavian reading audiences.

\section{Publication and Circulation}

Right from the outset, two important factors restricted Ibsen's domestic, Scandinavian market. First, there was the issue of price. Before the publication of the first collected edition of Ibsen's works in I898, no cheap editions of his writings were published in the Nordic countries. Secondly, there was the issue of translation to Swedish. Ibsen was among the authors who enforced the view that Scandinavians should read each other's literature in the original language, and he would consequently not allow translations of his works into Swedish. While the lack of translation was no major obstacle for the academic and bourgeois readerships, many less educated readers arguably struggled to read Danish or Dano-Norwegian. Swedish public libraries were, furthermore, reluctant to acquire foreign language literature, contributing further to limiting Ibsen's readership in the most populous among the Nordic countries. Correspondence and sales' figures from Swedish booksellers suggest that only around io to 20 per cent of copies of Ibsen's books ended up in the Swedish market. Despite the restrictive translation policy and the original books being expensive, Ibsen books sold in remarkable numbers, particularly when 
taking into account that Denmark and Norway had a total population of just around 4 million people.

The expansion of Ibsen's book market followed a common European pattern, which saw rapidly growing print runs by the end of the nineteenth century. Ibsen was eventually able to break the 10,000 barrier, and he thereby joined the ranks of some of the most successful writers of the time, among them Jules Verne and Émile Zola, who were writing for a linguistic community ten times as large as the Danish-Norwegian and whose works appeared mainly in very cheap 'popular' editions. Norwegian writers in fact appreciated the strength of their domestic market. Writing to his publisher Jacob Hegel from Paris in I888, the novelist Alexander L. Kielland declared that in my opinion there is no nation today where as many books are being read as in Scandinavia'. ${ }^{\mathrm{I}} \mathrm{His}$ colleague Jonas Lie compared Scandinavia favourably to Germany right from his first visits there in the late I 870 . In I 897 he was still struck by 'book conditions' in the enormous Germany being so 'small and petty compared to our Norwegian-Danish ones'.

In terms of print runs, 'the four great ones' of Norwegian literature, Ibsen, Bjørnson, Lie and Kielland, were ahead of their Scandinavian colleagues, and Ibsen surpassed them all. From early on, there was an unprecedented news interest in Ibsen publications, which helped to create a strong and lasting interest in his books and plays among the general public, and to establish his writings and plays as a recurring subject of discussion. 'Ibsen's books had to be read as soon as they were published,' the Swedish author and historian Lydia Wahlström wrote in her memoirs. ${ }^{3}$ When new books by Ibsen or Bjørnson arrived at the quay in Kristiania in the 1880 s, representatives of the bookshops collected the cargo as soon as it was landed and cleared, brought it up to the shop in a hurry and then out to eagerly waiting customers. New Ibsen books were by this time met with great anticipation and some newspapers would give a summary of the play's action in their evening edition, hastily compiled in a matter of hours by literary reporters the same day that the long-awaited new book had arrived in the capital.

The shipping of Ibsen's books was carefully coordinated in order for them to reach their most important destinations simultaneously throughout Scandinavia. For the booksellers, it was crucial to acquire the new Ibsen book as soon as possible; one day back or forth mattered a great deal, and delays could inflict economic losses. Indeed, according to the sales ledgers from Albert Cammermeyer's bookshop in Kristiania, the largest in Norway, and Gumpert's bookshop in Gothenburg, one of the largest in 
Sweden, most copies of a new Ibsen book were bought shortly after they arrived, if not on the very same day. The consequences of a slow delivery were felt even more strongly in the provinces. In an I88I letter to Gyldendal, the bookseller Wilhelm Holmboe in Tromsø in northern Norway complained that the copies he ordered of Ibsen's books usually arrived two or three weeks after his competitors in Kristiania received theirs. As a consequence, the bookseller stated, his customers were growing impatient, and several of them ordered the book from Kristiania instead and passed it around between them. ${ }^{4}$

After the transition to the publishing house Gyldendal in Copenhagen, Ibsen's books were printed in ever larger editions. Looking specifically at reprints, we can identify a 'basic market' for a book; when a new edition is sold only sporadically over a long time, we might say that the basic market has been saturated and we can delimit it. On this basis, Ibsen's publishing history with Gyldendal can be divided into three phases. From Brand to Emperor and Galilean (I866-73), 6,000 to 8,000 copies were enough to satisfy the need of the basic market. From Pillars of the Community to The Master Builder (1877-92), demand expanded to $c$. 10,000 copies, which was also the extent of most first editions in the I88os. From Little Eyolf to When We Dead Awaken (1894-9), the basic market grew even further and I 2,000 copies were the minimum needed in order to meet demand.

None of Ibsen's Scandinavian colleagues were able to achieve such high print runs. The first editions of Kielland's Poison (I883), Lie's One of Life's Slaves (1883) and Bjørnson's A Gauntlet (1883) were published in 6,000 copies each. Two of the leading Danish authors, J.P. Jacobsen and Holger Drachmann, were by this time issued in first editions of 2,500-3,000 copies. In Sweden, August Strindberg's works were rarely printed in more than a few thousand copies. The first volume of his Getting Married (I 884) was printed in 4,000 copies, and the eight books by Strindberg published in the timespan I 887-90 by Albert Bonnier, had an average print run of less than $3,000 .{ }^{5}$ Other contributors to the literature of the Modern Breakthrough did not fare nearly as well, and some of the disheartening characterizations of the relations between the Scandinavian modern authors and the reading public during the late nineteenth century may not be entirely inaccurate after all. But such claims cannot be reconciled with the fact that some of these authors were downright bestsellers. At Gumpert's bookshop in Gothenburg, the Modern Breakthrough literature accounted for around a fifth of the fiction sales, largely thanks to Strindberg, who was the overall bestselling fiction author, and at Cammermeyer's bookshop in Kristiania, Ibsen's works proved to be bestsellers again and again. 
The impression of opposition to Ibsen's modern literature is thus largely based on the hostile criticism of Ghosts (I88I) and the reports of numerous copies of the play being returned to the publisher. Georg Brandes claimed that 'nearly all the copies that were sent from Copenhagen to Norway were returned undisposed'. ${ }^{6}$ Such reports are wildly exaggerated. It is an indisputable fact that many copies of the book were returned and that it faced negative reviews; it is equally true that thirteen years passed before a new edition was called for. But the main reason for this is that Ghosts is located in the middle of Gyldendal's transition from printing several small editions to printing a large first one. Spurred by the huge commercial success of A Doll's House (1879), which had reached a total print run of I 3,500 copies in its first twelve months, the publisher Frederik V. Hegel ordered a record high of I0,000 copies for Ghosts. The first edition of Ghosts did not sell out quite as quickly as the first edition of $A$ Doll's House, but it compares well with any other Ibsen play until the late I890s. The immediate negative response has overshadowed the fact that Ghosts was actually a sales success on the same level as An Enemy of the People (1882) and The Wild Duck (I884).

\section{Tracing Readers}

Around the publication of $A$ Doll's House, the publisher Hegel noted an interest among hitherto unknown provincial readers in Denmark, in ... places that do not otherwise distinguish themselves in terms of literary interest'. ${ }^{7}$ Expanding print runs show that Ibsen continuously widened his circle of readers. His modern drama found its way to a new audience, without necessarily alienating his old followers. Among the customers who bought An Enemy of the People from Cammermeyer's bookshop, for example, were academics, wholesalers, physicians, shopkeepers, factory owners, officials, clerics and law clerks, as well as unmarried and widowed women. Bookshops were at the centre of the most exclusive literary circuits, catering for a wealthy readership to whom price was not a major concern. This is clearly reflected in the socio-economic status of the customers buying Ibsen's books. In Sweden, Ibsen customers in Gumpert's bookshop were largely the same as in Kristiania: wholesalers, unmarried women, law officials, commissioned officers and bookkeepers. In the bookshop of a provincial Swedish town, Västerås, the Ibsen clientele comprised grammar school teachers, officials, estate owners, commissioned officers and unmarried women.

Comparing the Swedish customers who bought Modern Breakthrough literature in general, and Ibsen's books in particular, to the general 
bookshop clientele, we find several notable differences. The picture of the Ibsen clientele that emerges is one of a highly educated and well-to-do group, representing a rather narrow social stratum. Wealthy wholesalers and other members of the trade aristocracy belong to the most important category of Ibsen buyers, and even members of the nobility, a group that was frequently described as uninterested or downright hostile towards this literary movement, acquired Ibsen's writings. Ibsen attracted readers of a higher social standing, a more exclusive readership than, for example, Bjørnson. There were not many middle-class customers buying Ibsen's books at Gumpert's bookshop in Gothenburg, although some tendencies, such as the presence of bookkeepers, teachers, cashiers and clerks among the customers, point toward a slow democratization of his clientele. The sales records from the bookshops in both Gothenburg and Västerås also show that Ibsen managed to attract a significant female readership. Around IO-I 5 per cent of copies of books by Ibsen sold in the bookshops were bought by women in their own name, and many more female readers are probably hidden behind male customer names. By contrast, the books by Ibsen's rival Strindberg were rarely bought by women. Only around 2 per cent of the customers who bought books by the Swede were women.

The source materials from the bookshops of Gumpert and Cammermeyer consist of credit purchases. Records detailing the purchases made by cashpaying customers have not been preserved. This may, to some extent, explain why the new middle-class readership is not clearly visible in the archives of these two bookshops. The fact that Ibsen attracted new middleclass readers is, however, evident if we look at other literary circuits. The library at a provincial teacher training college in Tromsø bought Ibsen's works regularly right from his Gyldendal debut with Brand in I866. The Norwegian teacher-training colleges were all, until the I890s, conservative institutions controlled by the church, largely recruiting peasant students. At the college in Tromsø, Ibsen was read mainly by the teachers and just a few students throughout most of the i 860 os and '70s. This changed completely by the end of the I870s, however, and particularly with $A$ Doll's House. A Doll's House was almost permanently on loan for two years and it also sparked interest in Ibsen's earlier plays. Among the students who graduated in I88I, over 80 per cent had borrowed one or more Ibsen title.

\section{Primary and Secondary Readerships}

These students may be said to have belonged to Ibsen's secondary audience. The primary audience consisted of a relatively small but qualified and 
well-to-do pan-Scandinavian readership, who would purchase his books more or less immediately following publication. This chiefly urban group of readers was composed of members of the public who were able to spend both time and money staying attuned to the literary currents of the day. They were the ones who could afford to subscribe to newspapers and magazines, and who mastered foreign languages. They belonged to something of a transnational reading community, and their identity as readers was shaped as much by their socio-economic status as by their geographical location. A university professor in Copenhagen, a physician in Gothenburg or a lawyer in Kristiania, and other members of Ibsen's primary audience, would have been able to read the same book at the same time, and they arguably had more in common with one another when it comes to cultural influence than readers of limited means on their own turf. Less affluent members of the primary audience were able to buy a book by Ibsen every now and then, but were forced to weigh their options, and behind every purchase lay a carefully considered decision.

The secondary audience consisted of readers to whom buying a new book by Ibsen was usually not within reach. Readers of limited economic means were dependent on libraries, reading societies and the second-hand market in order to access reading materials, and they were sometimes in for a long wait before the must-haves of the upper classes came within their reach. Literary institutions catering to the general public, such as the public libraries, often avoided literature that could be perceived as controversial or radical. Swedish parish libraries, for example, which were the goto places for rural readers, were particularly conservative. By contrast, Modern Breakthrough literature was something of a niche for the private institutions such as the commercial lending libraries, but these were located in the cities and furthermore charged the borrowers a higher fee than the public institutions. For a long time, readers of limited means were unable to access books by authors such as Strindberg and Ibsen. As late as in I886 a celebrated institution like the large workers' library in Gothenburg, with over 2,000 volumes of fiction, only had two books by Ibsen on offer - Brand and The League of Youth, both from the I860s and not a single book by Strindberg. By the I 890 os things were changing. Little by little - arguably following public demand - Ibsen's books found their way to more and more libraries in Sweden and thereby came within reach of groups of readers who were unable to buy the books from the bookshop. In I 895, J.A. Sjöblom's commercial lending library in the city of Lund, southern Sweden, offered at least seven of Ibsen's books, ranging from The Vikings at Helgeland (18 58) to Hedda Gabler (I 890). By then, 
Sjöblom's library mainly catered to lower-class readers, and his clientele consisted chiefly of unskilled workers, schoolboys and unmarried women.

In a private reading society in Grue in rural Norway, where the majority of the members were farmers, Ibsen was the second most borrowed author in the I870s, after Eugène Sue. Peer Gynt (1867) was the single most borrowed book, and Emperor and Galilean (1873) was just a few loans behind. The reading society became a parish library in I88o, when new statues and acquisition policies were implemented. In the timespan I 880-6, the library only acquired two of Ibsen's 'contemporary' plays: Pillars of the Community (1877) and An Enemy of the People (1882). According to the new statutes, the library should stay away from anything that was 'subversive to Christianity, morality and the established social order', and that is presumably the reason why the library did not acquire A Doll's House (1879), Ghosts (1881), The Wild Duck (1884) or Rosmersholm (I 886). Regardless of the statutes, however, the borrowers seemed to prefer Ibsen's verse dramas and historical plays, and Peer Gynt achieved twice as many loans as the two 'contemporary' plays. The library of the Cabinet Makers' Association in Kristiania echoes this tendency. Here, Peer Gynt achieved three times as many loans as John Gabriel Borkman (I896) and When We Dead Awaken (1899) combined, between 1896 and I9I8. In Tromsø, the teacher training college kept out the politically most controversial authors of the I $88 \mathrm{os}$, like Bjørnson and Kielland, but Ibsen seems to have been above reproach. They did not buy Ghosts or Rosmersholm, but they systematically acquired every other Ibsen title. Cammermeyer's records show that An Enemy of the People was ordered by at least seventeen associations and libraries. Kristianias's Athenæum, The Women's Reading Association and the Norwegian Association for Crafts and Industry acquired the book, as did several parish libraries.

\section{Everyman's Ibsen}

Three decades after the publication of Brand, Ibsen's books were attracting new cohorts of readers further down the social ladder, via public and private libraries and reading societies. By the end of Ibsen's career, there was also a change in pricing policy when Ibsen's Collected Works (I 898-I 902) finally offered his plays at a significantly lower price - around a third of the regular price per play. The new Gyldendal director, Peter Nansen, claimed that he had to fight the company veteran August Larsen to realize the edition; why should they sell Ibsen cheap, Larsen asked, when the expensive books sold so well? ${ }^{8}$ The author himself supported the 
decision: 'I have already long wished for such a one in order to secure my collected works a distribution in classes of society that the more expensive editions have difficulties reaching,' he wrote to his publisher in 1898.9 These collected works were printed in 15,000 copies and were a highly profitable enterprise for all parts.

By the turn of the century, then, the boundaries between the 'primary' and the 'secondary' Ibsen audiences were gradually dissolving, and the readers who could afford to buy a book by Ibsen were no longer a narrow elite. When Ibsen died in 1906, a 'Memorial Edition' (Mindeudgave, I 906-7), found its way to readers of even smaller means. Ibsen's son Sigurd reported to his mother that the publisher was exceedingly satisfied with the sales and that this time Norwegian subscribers were in a majority. The audience, Sigurd continued, consisted, 'remarkably, to a great extent, of readers from the deep and wide layers [of society]: craftsmen, store clerks and even servants can be found in great numbers among the subscribers' ${ }^{\text {IO }}$ By 1908, this edition had reached a total print run of almost 36,000 copies.

\section{Notes}

I. Alexander L. Kielland, Letter to J. Hegel, 9 February I 888, in Brev, ed. Johs. Lunde, vol. 2 (Oslo: Gyldendal, I978-8I), p. 237.

2. Jonas Lie, Letter to A. Garborg, I I November I 897, in Brev, ed. Anne Grete Holm-Olsen (Oslo: Novus, 2009), p. I 434.

3. Lydia Wahlström, Trotsig och försagd: mitt livs minnen (Stockholm: Natur och Kultur, I949), p. 7 I.

4. W. Holmboe, Letter to F.V. Hegel, io November I88I, The Gyldendal Archive, The Royal Danish Library, Copenhagen.

5. Johan Svedjedal, Bokens sambälle: Svenska bokförläggareföreningen och svensk bokmarknad I887-1943 (Stockholm: Svenska bokförläggareföreningen, I993), p. 43.

6. Georg Brandes, Henrik Ibsen (Copenhagen: Gyldendal, I 898), pp. I42-3.

7. Quoted in Narve Fulsås and Tore Rem, Ibsen, Scandinavia and the Making of a World Drama (Cambridge: Cambridge University Press, 20 I 8), p. I I 2.

8. Peter Nansen, Mine 20 Aar i Gyldendal (Copenhagen: L. Levison Jun. I9 I8), p. 19.

9. Quoted in Fulsås and Rem, Ibsen, p. 208.

Io. Sigurd Ibsen, Letter to Susanna Ibsen, 3 October 1906, National Library of Norway, Oslo, Letter collection 200 A. 